DOI https://doi.org/10.18551/rjoas.2020-12.23

\title{
PLANKTON COMMUNITY STRUCTURE AND FISH'S EATING-HABITS CHANGE IN RAWA BANGKAU, SOUTH KALIMANTAN
}

\author{
Rahman Abdur ${ }^{1 *}$, Dekayanti Tri $^{1}$, Khasanah Ruly Isfatul ${ }^{2}$, Sofarini Dini ${ }^{1}$, Noviani Eka ${ }^{3}$ \\ ${ }^{1}$ Aquatic Resources Management Study Program, Faculty of Fisheries and Marine Sciences, \\ Lambung Mangkurat University, South Kalimantan, Indonesia \\ ${ }^{2}$ Marine Science Study Program, Faculty of Science and Technology, \\ Sunan Ampel State Islamic University, Surabaya, Indonesia \\ ${ }^{3}$ Student of Aquatic Resources Management Study Program, Faculty of Fisheries and Marine \\ Sciences, Lambung Mangkurat University, South Kalimantan, Indonesia \\ *E-mail: rahmantrk@gmail.com
}

\begin{abstract}
The waters of Rawa Bangkau monotonous swamp, including the South Hulu Sungai Regency, potentially have several types of swamp fish that are economically valuable, quite high-priced, and popular with the South Kalimantan people. To date, there has been limited data about the lake and the resources it holds; the data is essential for proper management, among which are about the organisms making up the lake. Accordingly, the objectives of this study were (1) to obtain data and study the conditions of water quality and biology of Rawa Bangkau by examining the structure of the plankton community, (2) to clarify the stomach contents of Swamp fish, and (3) to analyze changes in Swamp fish food through a preference index (choice) based on Ivlev, 1961. The researchers carried out sampling in July-August 2020. The measurement results showed that: (1) DO (Dissolved Oxygen) measurements showed that the water conditions were not suitable for aquatic biota and lightly polluted. The nitrate content was in mesotrophic to oligotrophic conditions. The study site's abundant and diverse plankton showed low to moderate values, which was the same case with the uniformity and dominance index; (2) Fish guts indicated that the fish food was relatively the same as what was available in the waters (plankton); (3) The fish's eating habits changed due to natural food unavailability. The preference index showed that fish did not choose their food type - they ate the planktons in the waters.
\end{abstract}

\section{KEY WORDS}

Plankton, fish, swamp, eating habit, choice index.

The government prioritizes the development of the Rawa Bangkau area in the Kandangan District (South Hulu Sungai Regency) and a small part of the North Labuan Amas District (Central Hulu Sungai Regency) in the Regional Spatial Plan (Indonesian: Rencana Tata Ruang Wilayah) of South Kalimantan Province. The areas have been preserving fishery reservoirs (fish stocking). Rawa Bangkau is inundated with water all year round; it has been preserving fish of rivers flowing in the western region of the Meratus Mountains and habitat for waterbird fauna that must be protected. This swamp functions as a water source, irrigation, groundwater infiltration for the surrounding community, flood control, and fishing activities (Mahreda and Dekayanti, 2012).

To date, there has been limited data about the lake and the resources it holds. The data is essential for proper management, including those about the organisms making up the lake, such as its microorganisms (plankton, for example). The number of organism species in waters can provide an overview of communities in these waters.

Biological information related to community structure referring to the index of species diversity $\left(\mathrm{H}^{\prime}\right)$, Uniformity $(\mathrm{E})$, and Dominance $(\mathrm{C})$ is often used to evaluate the state of an aquatic environment based on biological conditions. A stable environment is characterized by balanced conditions and various lives without a dominant species (Odum, 1996).

Changes in water quality can be viewed from the abundance and composition of phytoplankton, revealing the waters' state. Phytoplankton is a biological parameter and an 
indicator of the quality and level of water (bioindicator). Learning the saprobic coefficient value is one way to measure water quality; the saprobic coefficient is an index closely related to the level of pollution. It shows the water quality. The coefficient is revealed after learning the structure of the phytoplankton community in the waters.

The strategic issues of increasingly-real climate change lead to unpredictable seasons, directly changing the water's surface temperature. It will cause the dynamics of plankton availability as natural food for fish, which will affect the productivity of the fish in Rawa Bangkau. The change in natural food types is presumably clarified by analyzing the fish's stomach contents. The availability of fish with economic value is expected to support food security for the community. According to this background, this research is imperative.

\section{METHODS OF RESEARCH}

The research was conducted in Rawa Bangkau, Kandangan Sub-district, South Hulu Sungai Regency, and a small part of the North Labuan Amas District, Central Hulu Sungai Regency, South Kalimantan. The sample was taken for three months at two stations (Figure 1). Station 1 was in the center of a swamp, and station 2 was in the swamp outlet.

The tools and materials were used at sampling and sample observation.

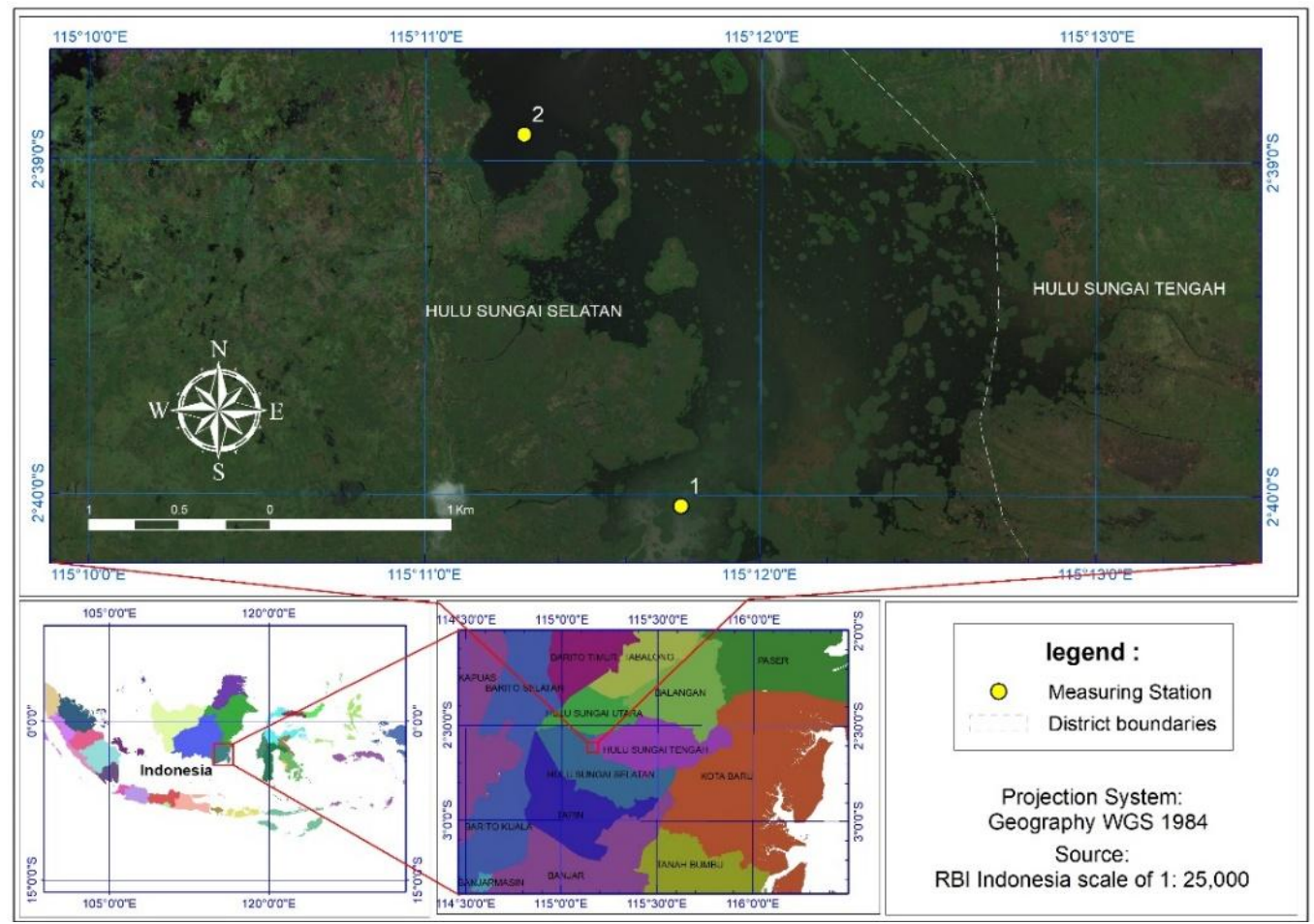

Figure 1 - Research location

Table 1 - Tools and materials used in plankton sampling

\begin{tabular}{lll}
\hline \multicolumn{2}{l}{ Sampling } & \\
\hline No & Tools and Materials & Purpose \\
\hline 1 & Plankton net & To collect plankton samples \\
2 & Sprayer & To spray plankton stuck to the plankton-net \\
3 & Sample bottles & To contain plankton samples (sample containers) \\
4 & Coolbox & To store plankton samples \\
5 & GPS & To determine the coordinates of the sampling location \\
6 & DO meter & To measure DO and seawater temperature \\
7 & Refractometer & To measure the pH and salinity of seawater \\
8 & Secchi disk & To measure water transparency \\
9 & Drop pipette & To transfer Lugol \\
10 & Lugol & To prepare plankton samples \\
11 & Stationary & To record the measurement results of water's physico-chemical parameters \\
12 & Net & To catch fish \\
\hline
\end{tabular}


Table 2 - Tools and materials used in sample observations

\begin{tabular}{lll}
\hline \multicolumn{2}{l}{ Sample Observation } & \\
\hline No & Tools and Materials & Function \\
\hline 1 & Microscope & To observe plankton samples \\
2 & SRCC (Sedgwick-Rafter Counting Cell) & To contain the samples \\
3 & Drop pipette & To collect plankton samples \\
4 & Plankton sample & The sample to be observed \\
5 & Measuring tube & To measure the sample volume \\
6 & Stationary & To record plankton observations \\
7 & Aquadest and Tissue & To clean the Sedgwick-Rafter Counting Cell (SRCC) \\
8 & Identification Book & To guide plankton identification \\
9 & Camera or Smartphone & To take photos of plankton observations \\
10 & Secchioset & To dissect the stomach contents of the fish \\
\hline
\end{tabular}

Sampling Procedure. Plankton sampling was carried out every two weeks and three times at each observation station. At each station, the researcher collected 25 liters of water and filtered it using plankton net no. 25. The remaining volume was $50 \mathrm{ml}$. The sample was put into the sample vials and preserved with a Lugol solution (4-6 drops in each sample bottle). Each sample-bottle was labeled. Next, the researchers identified the planktons under a microscope assisted with identification books from Needham (1962), Edmondson (1963), and Mizuno (1979).

Fish sampling was done simultaneously with plankton sampling. Fish samples were taken using fishing net with a 1 -inch mesh. The fish obtained were put into a $5 \mathrm{~kg}$ plastic bag and preserved in $10 \%$ formalin to prevent them from spoiling. Fish samples were identified in the Integrated Laboratory of Aquatic Resources Management Study Program, Lambung Mangkurat University, using the identification book Kottelat et al. (1993) and Needham \& Needham (1992).

Taking the physical parameters involved measurements of transparency and temperature. The chemical parameters measurement included measurement of $\mathrm{pH}$, salinity, dissolved oxygen (Dissolve Oxygen/DO), nitrate (NO3), and phosphate (PO4). The tools and methods for measuring physico-chemical parameters are shown in Table 3.

Table 3 - Tools and methods used in measuring the physico-chemical parameters of waters

\begin{tabular}{lllll}
\hline No & Parameter & Unit & Tool & Measurement Method \\
\hline 1 & Transparency & $\mathrm{M}$ & Secchi disk & In situ \\
2 & Temperature & ${ }^{\circ} \mathrm{C}$ & DO meter & In situ \\
3 & $\mathrm{pH}$ & - & pH paper & In situ \\
4 & Salinity & $\mathrm{Ppt}$ & Refractometer & In situ \\
5 & $\mathrm{DO}$ & $\mathrm{mg} / \mathrm{l}$ & DO meter & In situ \\
6 & Nitrite & $\mathrm{mg} / \mathrm{l}$ & Spectrophotometer & ${ }^{*}$ Laboratory \\
7 & Phosphate & $\mathrm{mg} / \mathrm{l}$ & Spectrophotometer & ${ }^{*}$ Laboratory \\
\hline
\end{tabular}

*Laboratory = MSP Lambung Mangkurat University Laboratory.

The abundance of plankton was calculated to find out the amount of plankton in the water. Plankton abundance is the number of individuals/plankton cells in water (cell/L or individual/L). Plankton abundance $(\mathrm{N})$ analysis can be calculated using the APHA formula (1989) (Equation [1]).

$$
N=\left(\frac{O i}{O p} \times \frac{V r}{V o} \times \frac{1}{V s} \times \frac{n}{p}\right)
$$

Where: $\mathrm{N}=$ The number of cells per liter (cells/liter); Oi = Cover glass area (mm2); Op = Field of view area $(\mathrm{mm} 2) ; \mathrm{Vr}=$ Filtered water volume $(\mathrm{ml}) ; \mathrm{Vo}=$ Sample under cover-glass volume $(\mathrm{ml}) ; \mathrm{Vs}=$ Filtered seawater sample volume $(\mathrm{L}) ; \mathrm{n}=$ The number of phytoplankton cells in all visual fields (cells); $p=$ The number of fields observed (mm2). 
According to Odum (1996), the abundance of phytoplankton can indicate the fertility indicator of water. Water fertility based on the abundance of phytoplankton can be seen in Table 4.

Table 4 - Water fertility based on phytoplankton abundance

\begin{tabular}{ll}
\hline Abundance $(\mathrm{N})$ & Category \\
\hline$>500 \mathrm{cell} / \mathrm{L}$ & High water-fertility \\
$<500 \mathrm{cell} / \mathrm{L}$ & Moderate water-fertility \\
\hline
\end{tabular}

According to Sri Artiningsih (2013), the diversity index is often referred to as diversity indexes. This analysis was used to determine the diversity of marine biota species. To determine the value of diversity, the researchers used the Shannon-Wiener diversity index (Odum, 1993) with Equation 2.

$$
H^{\prime}=-\sum_{i=0}^{i} P i \ln P i
$$

Where: $\mathrm{H}^{\prime}=$ diversity index; $\mathrm{Pi}=\mathrm{ni} / \mathrm{N} ; \mathrm{ni}=$ number of individuals of type $\mathrm{I} ; \mathrm{N}=$ total number of individuals.

According to the Shannon-Wiener equation, the diversity index value $\left(\mathrm{H}^{\prime}\right)$ is classified in Table 5 (Odum, 1993).

Table 5 - Shannon-Wiener Diversity Index

\begin{tabular}{ll}
\hline Diversity $\left(\mathrm{H}^{\prime}\right)$ & Category \\
\hline $0<\mathrm{H}^{\prime}<2.3$ & Low diversity level \\
\hline $2.3<\mathrm{H}^{\prime}<6.9$ & Moderate diversity level \\
\hline $\mathrm{H}^{\prime}>6.9$ & High diversity level \\
\hline
\end{tabular}

20 fish caught in the Rawa Bangkau waters were measured to determine the fish's average body length. The stomach was analyzed to determine the composition of the phytoplankton and zooplankton and the preference level of the fish's choice index in choosing food. The amount of plankton found in the fish's stomach was calculated using the volumetric method, while the food composition was calculated using the index of preponderance (Ivlev, 1961).

The composition of plankton contained in the fish stomach was compared to that in water. The comparison was presented in an 'absent-present' table containing the following information:

- The plankton components in the fish stomach in the water;

- Plankton components in the fish stomach that were not in the water;

- Plankton components that were not in the fish stomach but were in the water.

To determine the type of plankton, the fish's main choice of food, an index of electifity was used. It was done by comparing the amount of plankton in the fish stomach with the abundance of plankton types in the waters with the formula (Ivlev, 1961):

$$
E=\frac{r_{i}-p_{i}}{r_{i}+p_{i}}
$$

Where: $E=$ Index of choice; $r_{i}=$ The relative number of types of organisms eaten; $p_{i}=$ The relative number of organisms in the water.

The value of the choice index $(E)$ ranges from -1 to +1 , indicating that the closer the value to +1 , the more chance the fish choose the plankton as their food.

\section{RESULTS AND DISCUSSION}

The measured water temperature showed the highest value in sampling three-outlet stations: 32.5 OC. The central station and the outlet showed the same lowest-value in 
sampling 1: $28.50 \mathrm{C}$. The waters' natural temperature experienced fluctuation due to various factors, including sunlight and rain, heat exchange with air temperature, geographical location, and vegetation cover around Lake Bangkau. The water's temperature affected the organisms' activities, one of which was the planktons. According to Hilal (2020), the temperature in the range of $20-40 \mathrm{OC}$ is the optimal temperature for the photosynthesis process by phytoplankton as the main producer of waters, which differs from each type. The measured temperature in Rawa Bangkau showed an optimal temperature for zooplankton, which was in the range of 15-35 0C. According to Soliha et al. (2016), the temperature is a determining factor in aquatic biota's life because it affects the overall solubility of gases in water and all biological activities in aquatic ecosystems.

Table 6 - Measurement of Water Quality in Rawa Bangkau waters

\begin{tabular}{|c|c|c|c|c|c|c|c|c|}
\hline \multirow[t]{2}{*}{ No. } & \multirow[t]{2}{*}{ Parameter } & \multirow[t]{2}{*}{ Unit } & \multicolumn{2}{|c|}{$\begin{array}{l}\text { Sampling } 1 \\
\text { (27 July 2020) }\end{array}$} & \multicolumn{2}{|c|}{$\begin{array}{l}\text { Sampling } 2 \\
\text { (6 August 2020) }\end{array}$} & \multicolumn{2}{|c|}{$\begin{array}{l}\text { Sampling } 3 \\
\text { (16 August 2020) }\end{array}$} \\
\hline & & & Center & Outlet & Center & Outlet & Center & Outlet \\
\hline 1. & Temperature & ${ }^{\circ} \mathrm{C}$ & 28,5 & 28,5 & 28,2 & 31,5 & 31 & 32,5 \\
\hline 2. & $\mathrm{pH}$ & - & 6,29 & 6,25 & 6,01 & 6,01 & 5,99 & 6,07 \\
\hline 3. & Transparency & $\mathrm{Cm}$ & 93 & 73 & 85 & 100 & 77 & 79 \\
\hline 4. & DO & $\mathrm{mg} / \mathrm{l}$ & 1,7 & 2,4 & 2,2 & 1,3 & 1,7 & 1,7 \\
\hline 5. & Nitrite $\left(\mathrm{NO}_{2}^{-}\right)$ & $\mathrm{mg} / \mathrm{l}$ & 1,8 & 2,2 & 0,6 & 0,7 & 0,4 & 0,8 \\
\hline 6. & Phosphate $\left(\mathrm{PO}_{4}{ }^{-}\right)$ & $\mathrm{mg} / \mathrm{l}$ & 0,21 & 0,39 & 3,36 & 0,51 & 2,28 & 0,48 \\
\hline
\end{tabular}

The $\mathrm{pH}$ value is the acidity of the waters, which significantly affects aquatic plants and animals. The $\mathrm{pH}$ value of Rawa Bangkau ranged from $5.99-6.29$, with the highest value at the center of sampling station 1. According to Sholiha et al. (2016), the optimal pH value needed by phytoplankton in its growth is 6.0-8.0. The measurement results indicated that the waters' pH value in Rawa Bangkau supported plankton's life and growth: both phytoplankton and zooplankton.

Rawa Bangkau shows' transparency value ranged from $73-100 \mathrm{~cm}$, where the outlet station had a higher value in sampling 2 and 3 , but a lower value in sampling 1 . According to Faza (2012), the water's transparency affects the development and growth of phytoplankton that utilize the sunlight in the process of photosynthesis. The measured transparency was considered good with values above $60 \mathrm{~cm}$; thus, it still supported aquatic biota's life.

The field measurement results showed dissolved oxygen (DO) values ranging from 1.3 - $3.4 \mathrm{mg} / \mathrm{l}$, with the highest values found at the outlet of sampling station 1 . The DO levels in the water were created by photosynthesis by phytoplankton and oxygen diffusion from the atmosphere. The measurement results of less than $5 \mathrm{mg} / \mathrm{l}$ indicated that the water conditions were not suitable for aquatic biota and categorized as lightly polluted because DO levels have a vital role in determining the number of organisms in the waters. One of the determining factors of the DO level in waters is temperature. The high temperature increases aquatic biota's metabolism so that dissolved oxygen consumption is higher (IAS et al., 2012).

The studied location's nitrate content ranged from $0.4-2.2 \mathrm{mg} / \mathrm{l}$, in which sampling 1 showed a value between 1-5; thus, it was included in the mesotrophic category. Sampling 2 and 3 were included in the oligotrophic category with a value between $0-1 \mathrm{mg} / \mathrm{l}$. Nitrates have an essential role in planktonic life, such as photosynthesis and forming body fat and protein (Mustafa, 2015). Apart from nitrates, a nutrient that plays a vital role in the life of phytoplankton is phosphate. The phosphate values measured at the studied location ranged from 0.21 to $3.36 \mathrm{mg} / \mathrm{l}$ and were included in the eutrophic category because they exceeded the value of $0.1 \mathrm{mg} / \mathrm{l}$. According to the KepmenLH, this value is also included in the eutopic category because it is higher than 0.15 . Phytoplankton uses these nutrients as the basic ingredients for forming organic material, the main food source in the marine food chain. However, it has a limit. If it exceeds the limit, it leads to excessive algae growth, causing depletion of dissolved oxygen in the waters and disrupting aquatic life (Tungka, 2016; Maziyyah, 2019). The plankton community structure in Rawa Bangkau is described through three indices: diversity, uniformity, and dominance. The results of the calculation of each observation are presented Table 7. 
Table 7 - Plankton community abundance and structure index of sampling 1

\begin{tabular}{|c|c|c|c|c|}
\hline \multirow{2}{*}{ No } & \multirow{2}{*}{ Filum } & \multirow{2}{*}{ Genus } & \multicolumn{2}{|c|}{ Location } \\
\hline & & & Center & Outlet \\
\hline \multicolumn{5}{|c|}{ Phytoplankton } \\
\hline \multirow[t]{4}{*}{1} & Cyanophyta & Oscillatoria & 10 & - \\
\hline & & Microcystis & 10 & - \\
\hline & & Phormidium & 10 & - \\
\hline & & Gleothece & 30 & - \\
\hline \multirow[t]{2}{*}{2} & Chlorophyta & Gonatozygon & - & 100 \\
\hline & & Zygnema & 10 & - \\
\hline \multirow[t]{3}{*}{3} & Chrysophyta & Diatoma & 20 & 50 \\
\hline & & Synedra & - & 10 \\
\hline & & Rhopalodia gibba & 20 & - \\
\hline \multicolumn{3}{|c|}{ Abundance (Cell/liter) } & 110 & 160 \\
\hline \multicolumn{3}{|c|}{ Diversity Index (Shannon-Wiener) } & 1.8462 & 0.8305 \\
\hline \multicolumn{3}{|c|}{ Uniformity Index } & 0.9488 & 0.7560 \\
\hline \multicolumn{3}{|c|}{ Dominance Index } & 0.1736 & 0.4922 \\
\hline \multicolumn{3}{|c|}{ The Number of Taxa } & 7 & 3 \\
\hline \multicolumn{5}{|c|}{ Zooplankton } \\
\hline \multirow[t]{3}{*}{1} & Protozoa & Trichonympha & 20 & - \\
\hline & & Arcella & - & 350 \\
\hline & & Phacus & - & 20 \\
\hline 2 & Ciliophora & Coleps & - & 10 \\
\hline 3 & Crustacea & Diaptomus & 10 & - \\
\hline \multicolumn{3}{|c|}{ Abundance (individual/liter) } & 30 & 380 \\
\hline \multicolumn{3}{|c|}{ Diversity Index (Shannon-Wiener) } & 0.6365 & 0.3264 \\
\hline \multicolumn{3}{|c|}{ Uniformity Index } & 0.9183 & 0.2971 \\
\hline \multicolumn{3}{|c|}{ Dominance Index } & 0.5556 & 0.8518 \\
\hline \multicolumn{3}{|c|}{ The Number of Taxa } & 2 & 3 \\
\hline
\end{tabular}

Table 8 - Plankton community abundance and structure index of sampling 2

\begin{tabular}{|c|c|c|c|}
\hline \multirow{2}{*}{ Filum } & \multirow{2}{*}{ Genus } & \multicolumn{2}{|c|}{ Location } \\
\hline & & Center & Outlet \\
\hline \multicolumn{4}{|l|}{ Phytoplankton } \\
\hline $1 \quad$ Cyanophyta & Microcystis & 70 & - \\
\hline \multirow[t]{5}{*}{ Chlorophyta } & Gonatozygon sp & - & 10 \\
\hline & Chlorococcum sp & 20 & - \\
\hline & Netrium $s p$ & 10 & - \\
\hline & Closterium sp & - & 20 \\
\hline & Oocystis sp & - & 30 \\
\hline \multirow[t]{3}{*}{$2 \quad$ Chrysophyta } & Rhopalodia gibba & 220 & 30 \\
\hline & Coconeis sp & 30 & - \\
\hline & Pinnularia sp & 10 & 20 \\
\hline \multirow{5}{*}{\multicolumn{2}{|c|}{$\begin{array}{l}\text { Abundance (Cell/liter) } \\
\text { Diversity Index (Shannon-Wiener) } \\
\text { Uniformity Index } \\
\text { Dominance Index } \\
\text { The Number of Taxa }\end{array}$}} & 360 & 110 \\
\hline & & 1,1861 & 1,5466 \\
\hline & & 0,6620 & 0,9610 \\
\hline & & 0,4228 & 0,2231 \\
\hline & & 6 & 5 \\
\hline \multicolumn{4}{|l|}{ Zooplankton } \\
\hline \multirow[t]{3}{*}{ Protozoa } & Trichonympha sp & 20 & - \\
\hline & Arcella sp & - & 30 \\
\hline & Trachelomonas sp & 50 & 20 \\
\hline $2 \quad$ Ciliophora & Coleps sp & 160 & - \\
\hline Abundance (individual/liter) & & 230 & 50 \\
\hline Diversity Index (Shannon-Wiener) & & 0,7966 & 0,6730 \\
\hline Uniformity Index & & 0,7251 & 0,9710 \\
\hline Dominance Index & & 0,5388 & 0,5200 \\
\hline The Number of Taxa & & 3 & 2 \\
\hline
\end{tabular}

The center station's phytoplankton diversity index had a higher value than the outlet station (the center station was 1.85, and the outlet station was 0.83 ). In the zooplankton community, the highest diversity was found at the central station with a value of 0.64 . According to Hidayat et al. (2015), the diversity index value of less than 1 show that plankton diversity in an ecosystem is low and leads to low community stability. The high diversity in phytoplankton communities, whose values ranging from 1-3, indicates that the ecosystem's diversity is moderate.

Moreover, the uniformity index showed a high value at the center station. The uniformity index value was between $0-1$. A high uniformity value in an ecosystem indicates 
not much difference in each genus' number and leads to a lower dominance value in that location; the observation conducted in this research revealed this result. The low dominance value in an ecosystem indicated no dominance by one species in an ecosystem. Following Ma'arif (2018), the dominance value approaching 0 indicates the absence of dominance by an individual, followed by a high uniformity index.

The diversity value in sampling 2 decreased to 1.18 at the center station, and the outlet station's value increased to 1.54 . In contrast, the zooplankton community's diversity values increased at both stations. Plankton's diversity value in the water illustrated how high the species' variation was influenced by various factors, including their ability to adapt to the environment. The uniformity values of phytoplankton in center and outlet stations were between 1-3, putting them in the medium category with a relatively high community-stability level. In contrast, the zooplankton community had low diversity because its value was less than 1 (Hidayat et al., 2015). The phytoplankton and zooplankton uniformity indices decreased at the center station but increased at the outlet station. This result decreased the outlet station's dominance index; thus, it was smaller than the center station. According to Ambarwati (2019), if an ecosystem's uniformity value is high, the community has no dominant species.

Table 9 - Plankton community abundance and structure index of sampling 3

\begin{tabular}{|c|c|c|c|c|}
\hline \multirow{2}{*}{ No } & \multirow{2}{*}{ Filum } & \multirow{2}{*}{ Genus } & \multicolumn{2}{|c|}{ Location } \\
\hline & & & Center & Outlet \\
\hline \multicolumn{5}{|c|}{ Phytoplankton } \\
\hline 1 & Cyanophyta & Microcystis sp & - & 90 \\
\hline \multirow[t]{6}{*}{2} & Chlorophyta & Gonatozygon sp & 20 & 30 \\
\hline & & Spinoclosterium sp & 20 & - \\
\hline & & Oocystis sp & - & 10 \\
\hline & & Scenedesmus sp & - & 10 \\
\hline & & Spirogyra sp & - & 10 \\
\hline & & Ulothrix $s p$ & - & 10 \\
\hline \multirow[t]{4}{*}{2} & Chrysophyta & Synedra sp & 30 & - \\
\hline & & Rhopalodia gibba & 150 & 100 \\
\hline & & Nitzschia sp & - & 50 \\
\hline & & Navicula $s p$ & - & 10 \\
\hline \multicolumn{3}{|c|}{ Abundance (Cell/liter) } & 220 & 320 \\
\hline \multicolumn{3}{|c|}{ Diversity Index (Shannon-Wiener) } & 0,9688 & 1,7737 \\
\hline \multicolumn{3}{|c|}{ Uniformity Index } & 0,6988 & 0,8073 \\
\hline \multicolumn{3}{|c|}{ Dominance Index } & 0,5000 & 0,2148 \\
\hline \multicolumn{3}{|c|}{ The Number of Taxa } & 4 & 9 \\
\hline \multicolumn{5}{|c|}{ Zooplankton } \\
\hline \multirow[t]{5}{*}{1} & Protozoa & Arcella sp & 210 & 30 \\
\hline & & Trachelomonas sp & 40 & 20 \\
\hline & & Phacus sp & 30 & - \\
\hline & & Euglena $s p$ & - & 40 \\
\hline & & Euglypha sp & - & 10 \\
\hline \multirow[t]{2}{*}{2} & Ciliophora & Nassula $s p$ & 90 & 10 \\
\hline & & Actinosphaerium sp & 20 & - \\
\hline \multicolumn{3}{|c|}{ Abundance (individual/liter) } & 390 & 110 \\
\hline \multicolumn{3}{|c|}{ Diversity Index (Shannon-Wiener) } & 1,2549 & 1,4681 \\
\hline \multicolumn{3}{|c|}{ Uniformity Index } & 0,7797 & 0,9122 \\
\hline \multicolumn{3}{|c|}{ Dominance Index } & 0,3623 & 0,2562 \\
\hline \multicolumn{3}{|c|}{ The Number of Taxa } & 5 & 5 \\
\hline
\end{tabular}

In sampling 3, the outlet station's diversity index showed a higher value for both phytoplankton and zooplankton; 9 species were found, of which five were not much different from one another. According to Munthe et al. (2012), the community diversity index can indicate pollution in the waters. Diversity values ranging from 1-2 indicate that the waters are moderately polluted. If viewed from DO levels, a value less than five means that the waters are not suitable for aquatic biota. The measured nutrient elements with a value of less than one fall into the oligotrophic category, which are waters with low fertility.

The uniformity index values at both stations were less than 0.6 , so that it is included in the high uniformity category. These results indicated that the community in Rawa Bangkau was stable as the number of individuals between species was not too different. This result led to a low dominance index value of 0.36 at the center station and 0.25 at the outlet station. 
The dominance index value of less than 0.5 indicates no one-species domination in a community (Munthe et al., 2012).

The availability of food in the environment affected fish populations through food quality and quantity. In addition, several types of fish choose the food provided in their habitat; this caused different fish food composition in fish, albeit being the same type. The fish's ability to choose food provided by their habitat is referred to as the choice index. It is shown in Table 10.

Table 10 - Selection index (E) of fish caught in Rawa Bangkau waters

\begin{tabular}{|c|c|c|c|c|c|c|c|c|c|}
\hline \multirow[b]{2}{*}{$\begin{array}{l}\mathrm{N} \\
\mathrm{o}\end{array}$} & \multirow{3}{*}{ Filum } & \multirow[b]{2}{*}{ Genus } & \multicolumn{7}{|c|}{ E (Choice Index) } \\
\hline & & & $\begin{array}{l}\text { Three-spot } \\
\text { Gourami }\end{array}$ & $\begin{array}{l}\text { The } \\
\text { Perch }\end{array}$ & Climbing & $\begin{array}{l}\text { Snakeskin } \\
\text { Gourami }\end{array}$ & $\begin{array}{l}\text { Giant } \\
\text { Snakehead }\end{array}$ & $\begin{array}{l}\text { Snake-head } \\
\text { Murrel }\end{array}$ & $\begin{array}{l}\text { Kissing } \\
\text { Gouram }\end{array}$ \\
\hline & & & & & & & & & \\
\hline 1 & a & $\begin{array}{l}\text { Oscillatoria } \\
\text { Microcystis } \\
\text { Phormidium } \\
\text { Gleothece }\end{array}$ & $\begin{array}{l}-0.67 \\
0.25 \\
-0.54 \\
-1.00 \\
\end{array}$ & $\begin{array}{l}-1.00 \\
0.85 \\
-1.00 \\
-1.00 \\
\end{array}$ & & $\begin{array}{l}-0.51 \\
-0.51 \\
-0.72 \\
-1.00 \\
\end{array}$ & $\begin{array}{l}-1.00 \\
-1.00 \\
-1.00 \\
-1.00 \\
\end{array}$ & $\begin{array}{l}-1.00 \\
0.92 \\
-1.00 \\
-1.00 \\
\end{array}$ & $\begin{array}{l}-1.00 \\
0.92 \\
-1.00 \\
-1.00 \\
\end{array}$ \\
\hline 2 & Chloropyta & $\begin{array}{l}\text { Gonatozygon } \\
\text { Zygnema }\end{array}$ & $\begin{array}{l}-0.57 \\
0.89 \\
\end{array}$ & $\begin{array}{l}-0.29 \\
0.04 \\
\end{array}$ & & $\begin{array}{l}-0.46 \\
0.76 \\
\end{array}$ & $\begin{array}{l}0.15 \\
-1.00 \\
\end{array}$ & $\begin{array}{l}-0.74 \\
-1.00 \\
\end{array}$ & $\begin{array}{l}-0.82 \\
-1.00 \\
\end{array}$ \\
\hline 3 & $\begin{array}{l}\text { Chrysophyt } \\
\text { a }\end{array}$ & $\begin{array}{l}\text { Diatoma } \\
\text { Synedra } \\
\text { Rhopalodia } \\
\text { gibba }\end{array}$ & $\begin{array}{l}-0.51 \\
-0.43\end{array}$ & $\begin{array}{l}-1.00 \\
-0.30\end{array}$ & & $\begin{array}{l}-1.00 \\
-0.72\end{array}$ & $\begin{array}{l}-1.00 \\
-1.00\end{array}$ & $\begin{array}{l}-1.00 \\
-0.65\end{array}$ & $\begin{array}{l}-1.00 \\
-0.14 \\
-1.00\end{array}$ \\
\hline \multicolumn{10}{|c|}{ ZOOPLANKTON } \\
\hline & & & E (Choice In & & & & & & \\
\hline $\begin{array}{l}\mathrm{N} \\
\mathrm{O}\end{array}$ & Filum & Genus & $\begin{array}{l}\text { Three-spot } \\
\text { Gourami }\end{array}$ & $\begin{array}{l}\text { The } \\
\text { Perch }\end{array}$ & Climbing & $\begin{array}{l}\text { Snakeskin } \\
\text { Gourami }\end{array}$ & $\begin{array}{l}\text { Giant } \\
\text { Snakehead }\end{array}$ & $\begin{array}{l}\text { Snake-head } \\
\text { Murrel }\end{array}$ & $\begin{array}{l}\text { Kissing } \\
\text { Gouram }\end{array}$ \\
\hline 1 & Protozoa & $\begin{array}{l}\text { Trichonympha } \\
\text { Arcella } \\
\text { Phacus }\end{array}$ & $\begin{array}{l}-1.00 \\
-1.00 \\
0.85\end{array}$ & $\begin{array}{l}-1.00 \\
-0.94 \\
-0.27\end{array}$ & & $\begin{array}{l}-1.00 \\
-1.00 \\
-1.00\end{array}$ & $\begin{array}{l}-1.00 \\
-0.48 \\
-1.00\end{array}$ & $\begin{array}{l}-1.00 \\
-1.00 \\
-1.00\end{array}$ & $\begin{array}{l}-1.00 \\
0.08 \\
-1.00\end{array}$ \\
\hline 2 & Ciliophora & $\begin{array}{l}\text { Coleps } \\
\text { Spirostomum }\end{array}$ & $\begin{array}{l}-1.00 \\
-1.00 \\
\end{array}$ & $\begin{array}{l}0.94 \\
-1.00\end{array}$ & & $\begin{array}{l}0.95 \\
1.00\end{array}$ & $\begin{array}{l}-1.00 \\
1.00\end{array}$ & $\begin{array}{l}-1.00 \\
1.00\end{array}$ & $\begin{array}{l}-1.00 \\
-1.00\end{array}$ \\
\hline 3 & Crustacea & Diaptomus & -1.00 & -1.00 & & -1.00 & -1.00 & -1.00 & -1.00 \\
\hline
\end{tabular}

Table 10 shows that the choice index values ranging from -1 to +1 . The three-spot gourami's favorite food was the Zygnema species with a value of 0.89 , which was the highest percentage in sampling 1. Different results were shown in sampling 3; it was dominated by Rhopalodia gibba species with an index of -1 , despite the microcystins species' existence with an index of 0.25 . These results indicate that the wet springs' eating habits are not based on preferences but are thought to be influenced by other factors (Manangkalangi et al., 2010). The climbing perch was dominated by the Coleps species with an index of 0.94 , indicating that this type of zooplankton was the fish's favorite food. These results proved that most of the fish's stomach contents were the Coleps type; at each sampling, the values ranged between $69.23-100 \%$. These results show that climbing perch chose food in their environment based on the preference level. Tresna et al. (2012) stated that the fish's food composition is affected by abundance, preferences, and fish's physical factors.

Furthermore, the snakeskin gourami stomach analysis showed that the dominant food was the zygogonium and Coleps types in sampling 1; it was changed in sampling 2 and 3. The dominant type was Rhopalodia gibba, while Arcella $\mathrm{sp}$ was the least preferred food. These results indicated that snakeskin gourami consumed all types of food without any preference. The giant snakehead's dominant foods in sampling 1 were Spirostamum and Arcella sp. In contrast, sampling 2 was dominated by Coleps, the most disliked food of giant snakeheads. These results indicated that the snakehead disliked Arcella, and they preferred coleps as their main food even though they were not very popular. Thus, this type of fish did not choose their food based on their preference. The snakehead fish found in sampling 1 and 2 mostly fed on the Spirostamum, which was their favorite food with an index of 1 . In sampling 3, they mostly had the Coleps, even though it was the least preferred food with an index of -1 . It indicated that the snakehead fish had a preference and fed on the environment's greatest amount (Desrita, 2011).

The last fish found were the kissing gouramis, the omnivore fish. The stomach contents analysis showed that the dominant food was different in each observation carried out in the phytoplankton group. In sampling 1, the most-favored food was the Microcystis type with an index of 0.92 , while the dominant foods in sampling 2 and 3 were those disliked by the fish. 
From the zooplankton group, Arcella sp. Arcella was the food preferred by kissing gouramis, despite its low index value (0.08). These results indicated that Rawa Bangkau was dominated by fish that ate abundant food in the environment, not based on preferences. The phytoplankton found in the carnivorous fish stomach (or its absence) showed a change in their eating habits, one of which was due to environmental quality degradation (Syahputra et al., 2016).

\section{CONCLUSION}

The DO measurements showed that the water condition was not suitable for aquatic biota and lightly polluted; the nitrate content indicated mesotrophic to oligotrophic conditions. Likewise, the abundance and diversity of plankton at the study site showed low to moderate values with the uniformity and dominance indices. The fish stomach proved that the fish food was relatively the same (plankton). The fish's eating habit was changed due to natural-food unavailability. The preference index showed that fish did not choose their type of food. They ate planktons in the environment.

\section{ACKNOWLEDGMENTS}

The researchers would like to express gratitude to the Institute for Research and Community Service, University of Lambung Mangkurat through the Compulsory Research Lecturer Program Scheme for funding this research.

\section{REFERENCES}

1. Ambarwati M. 2019. Pengaruh Faktor Fisika-Kimia Perairan terhadap Kelimpahan and Keanekaragaman Plankton di Ekosistem Terumbu Karang Alami and Buatan Perairan PLTU Paiton. Skripsi. UIN Sunan Ampel. Surabaya.

2. Desrita. 2011. Bioekologi Ikan Bunga Air (Clupeichthys goniognathus) di Perairan Inlet Waduk Koto Panjang Kabupaten Kampar Provinsi Riau. Thesis. IPB. Bogor

3. Faza, M. F. 2012. Struktur komunitas plankton di sungai pesanggrahan dari bagian hulu (Bogor, Jawa Barat) hingga bagian hilir (Kembangan, DKI Jakarta). Skripsi. Universitas Indonesia, Depok.

4. Hidayat Dedi,. dkk. 2015. Keanekaragaman Plankton di Danau Simbad Desa Pulau Birandang Kecamatan Kampar Timur Kabupaten Kampar Provinsi Riau. Journal FMIPA. Vol 2 (1).

5. Hilal, M. 2020. Struktur komunitas Fitoplankton and Zooplankton berdasarkan Musim di Kawasan Danau Biru Cigaru Cisoka Kabupaten Tanggerang. Skripsi. UIN Syarif Hidayatullah.

6. Icas A. D. dkk. 2019. Identifikasi Isi Lambung Ikan Kapaet Osteochilus sp. asal Papua Bangka sebagai Dasar Pengembangan Domestikasi. Journal of Aquatropica Asia. Vol 4 (1): 16-19.

7. Ma'arif Chusnan. 2018. Perbandingan keanekaragaman and Kelimpahan Plankton pada Ekosistem Terumbu Karang Alami dengan Terumbu Karang Buatan di Perairan Pasir Putih Situbondo. Skripsi. UIN Sunan Ampel. Surabaya.

8. Manangkalangi E. dkk. 2010. Preferensi Makanan Ikan Pelagis Arfak, Melanotaenia arfakensis Allen, 1990 di Sungai Nimbai and Sungai Aimasi, Manokwari. Jurnal Ikhtiologi Indonesia. Vol 10 (2): 123-135.

9. Munthe Y. V. dkk. 2012. Struktur komunitas and Sebaran Fitoplankton di Perairan Sungsang Sumatra Selatan. Maspari Journal. Vol 4 (1): 122-130.

10. Mustafa, Arif. 2015. Kandungan Nitrat and Fosfat sebagai Faktor Tingkat Kesuburan Perairan Pantai. Jurnal Disprotek.Vol. 6: 1.

11. Nisa, K. dkk. 2013. Pengaruh pH pada Media Air Rawa terhadap Kelangsungan Hidup and Pertumbuhan Benih Ikan 
12. Odum, E. P. 1993. Dasar-dasar Ekologi. Edisi ketiga. Terjemahan: Samingan, T., Srigandono. Fundamentals Of Ecology. Third Edition. Gadjah Mada University Press

13. Odum, E. P. 1996. Dasar-dasar Ekologi. Gadjah Mada University Press

14. Soliha E. dkk. 2016. Kualitas air and keanekaragaman planton di danau cikaret, cibinong, bogor. Ekologia. Vol 16 (2).

15. Syahputra A. dkk. 2016. Kebiasaan Makan Ikan Lotok (Opiochara porochepala) di Perairan Sungai lyu, Kecamatan Bendahara, Kabupaten Aceh Tamiang, Provinsi Aceh. Jurnal IImiah Mahasiswa Kelautan and Perikanan Unsyiah. Vol 1 (2): 177-1844.

16. Tresna L. K. dkk. 2012. Kebiasaan Makanan and Luas Relung Ikan di Hulu Sungai Cimanuk Kabupaten Garut, Jawa Barat. Jurnal Perikanan and Kelautan. Vol 3 (2): 163173.

17. Tungka, A. W. dkk. 2016. Konsentrasi Nitrat and Ortofosfat di Muara Sungai Banjir Kanal Barat and Kaitannya dengan Kelimpahan Fitoplankton Harmfull Algae Blooms (HABs). Journal Fisheries Science and Technology. Vol. 12 (1): 40-46. 